\title{
Toxocariasis and Toxoplasmosis in Children with Idiopathic Epilepsy in Mid-Region of the Nile Delta, Egypt: Prevalence and Risk Factors
}

\author{
Amina M. Salama ${ }^{1}$, Ahmed A. Daoud ${ }^{1}$, Azza K. Elshehawy ${ }^{2}$, \\ Ahmad A. Othman ${ }^{1}$, Mohamed M. Eid ${ }^{1}$ \\ ${ }^{1}$ Department of Medical Parasitology, ${ }^{2}$ Department of Pediatrics, Faculty of Medicine, \\ Tanta University, Egypt \\ *Corresponding author
}

\begin{tabular}{|c|}
\hline Keywords \\
\hline $\begin{array}{l}\text { Toxocara canis, } \\
\text { Toxoplasma gondii, } \\
\text { epilepsy, ELISA, } \\
\text { Western blotting }\end{array}$ \\
\hline Article Info \\
\hline $\begin{array}{l}\text { Accepted: } \\
\text { 07 January } 2019 \\
\text { Available Online: } \\
\text { 10 February } 2019\end{array}$ \\
\hline
\end{tabular}

\section{Introduction}

Childhood epilepsy is one of the most important neurological disorders in both developing and developed countries. Epilepsy has an impact on both mental and physical health of children. Epileptic children may
Epilepsy is one of the most common and important neurological disorders among children especially in developing countries. Toxoplasma gondii (T. gondii) is an intracellular protozoan capable of forming cysts in the brain of chronically infected humans. Moreover, the larvae of Toxocara canis ( $T$. canis) can locate in the central nervous system leading to several neurological disorders. This study was undertaken to identify the prevalence and risk factors of toxocariasis and toxoplasmosis in children with idiopathic epilepsy. This study was conducted on 150 children aged 2-15 years, including 100 children suffering from idiopathic epilepsy and 50 apparently healthy children as a control group. All children were submitted to clinical questionnaire. They were tested for the presence of anti-Toxocara IgG by ELISA and western blotting, and for presence of anti-Toxoplasma IgG and IgM by ELISA and avidity test. The frequency of Toxocara infection in epileptic patients was $13 \%$ versus $4 \%$ of the healthy group by ELISA. By western blotting technique, Anti-Toxocara IgG antibodies were detected in $7(53.8 \%)$ of ELISA positive children in epileptic children group, whereas the serum samples of all ELISA-positive normal children were negative. Contact with dogs is the main risk factors for toxocariasis. Regarding T. gondii, by ELISA, 74 (74\%) epileptic children had anti-T. gondii antibody, 59 had Toxoplasma IgG only, 3 cases had Toxoplasma IgM only, and 12 cases had both Toxoplasma IgG and IgM. Moreover, 20 (40\%) normal children had positive results. Residence, contact with cats, contact with soil, and drinking unfiltered water are important risk factors for toxoplasmosis. There was significant association between toxoplasmosis and idiopathic epilepsy. Despite being statistically insignificant, the association between Toxocara infection and epilepsy still needs further investigation. 
2014). Infectious agents are implicated in its etiology. Several epidemiological studies have investigated the role of some helminths and protozoa such as Taenia sollium, Toxocara, Plasmodium, and Toxoplasma in causing epileptic attacks (Sander and Perucca, 2003; El-Tantawy et al., 2013).

Toxocariasis is one of the most commonly reported zoonotic infections in the world. It is a helminthic disease caused by two species of the ascarid nematodes Toxocara canis ( $T$. canis) and to a lesser extent $T$. cati (Macpherson, 2013). Toxocariasis carries a major health risk especially in the developing countries due to untreated and uncontrolled definitive hosts, poor hygiene, geophagia, lower education levels, and poverty which provide ideal transmission opportunities (Oryan et al., 2010; Congdon and Lloyd, 2011). Children are more susceptible to this infection because they handle contaminated soil (Figueiredo et al., 2005).

Toxocariasis can be classified as visceral larva migrans, ocular larva migrans, covert toxocariasis and neurotoxocariasis (Fan et al., 2013).The larvae of Toxocara can reach the central nervous system (CNS) causing a variety of neurologic disorders. Toxocariasis has been suggested as a co-factor for epilepsy (Nicoletti et al., 2008).

Another parasitic infection which is thought to be associated with epilepsy is toxoplasmosis. Toxoplasmosis is caused by obligate, intracellular, parasitic protozoan called Toxoplasma gondii ( $T$. gondii). It is one of the most common parasitic infections in humans and other warm-blooded animals with worldwide distribution. It is estimated to cause infection in one-third of the world's human population (Tenter et al., 2000; Dubey and Jones, 2008). After acute toxoplasmosis, the infection becomes latent and becomes encysted especially in the central nervous system and in the muscle tissues for the life of the infected host (Dubey and Jones, 2008; Miller et al., 2009). It has several clinical manifestations ranging from asymptomatic infection to multiorgan involvement (Montaya and Liesenfeld, 2004).

Cerebral toxoplasmosis can cause seizures and intracranial mass lesions (Zibaei et al., 2011). The latent form of $T$. gondii is a common and dormant infection affecting the brain and has the potential to cause epilepsy (Yazar et al., 2003). However, a few data are available concerning seroprevalence of $T$. canis infection and the association between this infection, and toxoplasmosis with idiopathic epilepsy in Egypt.

The aim of this study was to identify the prevalence and risk factors of toxocariasis and toxoplasmosis in children with idiopathic epilepsy in Mid-Region of the Nile Delta, Egypt.

\section{Materials and Methods}

\section{Subjects}

This study was carried out in the period from July 2016 to July 2017. The nature of the study was explained to one of the parents or the legal guardian of the child. Informed consents were obtained, and ethics committee approved the protocol in compliance with the current standard laws.

This study was conducted on 150 children 2-15 years old including 100 children suffering from idiopathic epilepsy, as evidenced by history, normal general and neurological examination, and normal Magnetic resonance imaging (MRI) of the brain, who were attendants of Paediatric Neurology Unit of Tanta University Hospital (epileptic group) and 50 apparently healthy children as a control group. 


\section{Methods}

All children were subjected to history taking through a questionnaire including personal data; risk factors for Toxocara and Toxoplasma as contact with animals (dogs and cats), contact with the soil, and consumption of undercooked meat or unfiltered water; current complaints with special inquiry on fever, lymphadenopathy, skin lesions, other neurological manifestations, and eye manifestations; history of the present illness including onset, progress of their current disease, received treatment, and investigations. Careful physical and neurological examinations were done for all the participants.

Three milliliters venous blood sample was taken from epileptic and normal children under sterile condition. One $\mathrm{ml}$ of blood was collected in EDTA tube to be used for determination of total leucocytic count and differential leucocytic count for calculation of absolute eosinophilic count according to Dacie and Lewis (1992). Eosinophilia was categorized into mild $\left(600-1500\right.$ cells $\left./ \mathrm{mm}^{3}\right)$, moderate $\left(1500-5000\right.$ cells $\left./ \mathrm{mm}^{3}\right)$ and high (more than 5000 cells $/ \mathrm{mm}^{3}$ ) (Singh et al., 2009). The other $2 \mathrm{ml}$ of blood was centrifuged at $2000 \mathrm{rpm}$ for $10 \mathrm{~min}$; the separated serum was kept at $-20^{\circ} \mathrm{C}$ in sterile aliquots and labeled with the child name and number for the serological tests. Haemolyzed samples were not used to prevent any potential error in test results.

\section{Tests for anti-Toxocara IgG antibodies}

The separated serum samples were used for detection of anti-Toxocara IgG by Enzymelinked immunosorbent assay (ELISA). AntiToxocara antibodies $(\mathrm{IgG})$ were detected by a commercial ELISA kit (Diagnostic Automation/Cortez Diagnostics, Inc., California, USA) according to the manufacturer's instructions.
Positive cases with anti-Toxocara IgG with ELISA were reexamined with western blotting technique for confirmation relied also upon a commercial kit (LDBIO Diagnostics, Lyon - France) following the manufacturer's guidance.

\section{Tests for anti-Toxoplasma antibodies}

The separated serum samples were used for detection of anti-Toxoplasma IgG and IgM by ELISA. Enzyme-linked immunosorbent assay test (Institut VirionlSerion GmbH, Germany) was used for screening of all the samples fo anti- $T$. gondii $\operatorname{IgG}$ and $\operatorname{IgM}$ antibodies according to the manufacturer's instructions. Positive cases with anti- Toxoplasma IgG and IgM were re-examined with Toxoplasma IgG avidity test using The "DS-EIA-ANTITOXO-G-AVIDITY" kit (DSI S.r.1.Saronno (VA), Via A.Volonterio, 36a, 21047, Italy).

\section{Statistical analysis}

The data were analyzed statistically using SPSS version 22.0 software (IBM, Armonk, NY, United States of America). Qualitative data were expressed as frequency and percentage. Chi-square test and Fisher's test were used as tests of significance. The values of $P<0.05$ were considered to be statistically significant.

\section{Results and Discussion}

\section{Demographic data in epileptic and normal participants}

In epileptic children group, $58(58 \%)$ were males and $42(42 \%)$ were females, and the normal children group consisted of 24 males $(48 \%)$ and 26 females (52\%). The participants' ages ranged from 2 to 15 years. The differences were statistically insignificant as shown in table 1. 


\section{Seroprevalence of $T$. canis}

\section{Enzyme-linked immunosorbent assay (ELISA)}

According to ELISA results, 13 (13\%) epileptic children had anti-Toxocara IgG antibody. Out of the 50 normal children, 2 (4\%) had positive results and the difference was statistically insignificant $(P>0.05)$ as shown in table 2 .

\section{Western blotting technique}

Serum samples from Toxocara ELISApositive cases were investigated using western blotting. Anti-Toxocara IgG antibodies were detected in $7(53.8 \%)$ of ELISA-positive children in epileptic children, whereas the serum samples of all ELISA-positive normal children were negative by western blotting. There was no statistically significant difference between epileptic and normal children $(P>0.05)$ as shown in table 2 . The positive western blotting strips which indicate the presence of specific anti-Toxocara IgG in the samples showed at least two or more bands of low molecular weight between 24 and $35 \mathrm{kDa}$ as shown in figure 1 .

Regarding eosinophilia in seropositive cases, 6 cases $(85.7 \%)$ had high eosinophilia and 1 $(14.3 \%)$ case had moderate eosinophilia. There was significant association between eosinophilia and toxocariasis $(P<0.05)$.

\section{Risk factors of toxocariasis in epilepsy}

There were no statistically significant differences between seropositive and seronegative epileptic groups regarding age, gender, residence, contact with soil, eating undercooked meat. Regarding the role of contact with dogs as a risk factor for toxocariasis in epilepsy, there was significant difference between both groups $(P<0.05)$ as shown in table 3. It was found that children who were exposed to dogs were at 6 times higher risk of developing toxocariasis (OR, 6.442; 95\% CI, 1.175-35.307).

\section{Seroprevalence of $T$. gondii}

\section{Enzyme-linked immunosorbent assay}

There was statistically significant difference in $T$. gondii $\mathrm{IgG}$ antibodies between epileptic and normal children $(P<0.05)$. According to ELISA results, 74 (74\%) children with idiopathic epilepsy had anti-T. gondii antibody. Of the 74 seropositive epileptic children, 59 had Toxoplasma IgG only, 3 cases had Toxoplasma IgM only, and 12 cases had both Toxoplasma IgG and IgM. Out of the 50 normal children, $20(40 \%)$ had positive results as shown in table 4.

By using the avidity test for patients seropositive with $T$. gondii $\mathrm{IgG}$ and IgM antibodies, all tested positive sera showed high avidity.

\section{Risk factors for toxoplasmosis in epilepsy}

Regarding the role of residence, contact with cats, contact with soil, and drinking unfiltered water as risk factors for toxoplasmosis in epilepsy, there was significant difference between different groups $(P<0.05)$; whereas, there were no statistically significant differences concerning the age, gender or consumption of undercooked meat between different groups as shown in table 5.

It was found that epileptic children who lived in rural areas were at 23 times higher risk of developing toxoplasmosis (OR, 23.852; 95\% CI, 6.403-88 .852). Epileptic children drinking unfiltered water were at 15 times higher risk of developing toxoplasmosis (OR, 15.225; 95\% CI, 4.961-46.728). 
Types of seizures in seropositive epileptic children

Out of 74 epileptic children who were seropositive with toxoplasmosis, 49 cases (66.2\%) had generalized seizures, 16 cases (21.6\%) had focal seizures, and 9 cases $(12.2 \%)$ had absence epilepsy. There was statistically significant difference between the different types of seizures as shown in table 6 . Out of 7 epileptic children seropositive with toxocariasis, 5 cases $(71.4 \%)$ had generalized seizures, 1 case $(14.3 \%)$ had focal seizures, and 1 case $(14.3 \%)$ had absence epilepsy. There was statistically significant difference between the different types of seizures as shown in table 6 .

Table.1 The demographic data in epileptic and normal participants

\begin{tabular}{|c|c|c|c|c|c|c|c|c|}
\hline \multirow[t]{2}{*}{ Factors } & \multicolumn{2}{|c|}{$\begin{array}{c}\text { Epileptic } \\
\text { children } \\
(n=100)\end{array}$} & \multicolumn{2}{|c|}{$\begin{array}{c}\text { Normal } \\
\text { children } \\
(n=50)\end{array}$} & \multicolumn{2}{|c|}{$\begin{array}{c}\text { Total } \\
(\mathbf{n}=150)\end{array}$} & \multirow[t]{2}{*}{$\chi^{2}$} & \multirow[t]{2}{*}{$P$} \\
\hline & n & $\%$ & $\mathbf{n}$ & $\%$ & $\mathbf{n}$ & $\%$ & & \\
\hline $\begin{array}{c}\text { Age groups (years) } \\
2-<6 \\
6-<10 \\
10-15\end{array}$ & $\begin{array}{l}45 \\
40 \\
15\end{array}$ & $\begin{array}{l}45 \\
40 \\
15\end{array}$ & $\begin{array}{c}25 \\
18 \\
7\end{array}$ & $\begin{array}{l}50 \\
36 \\
14\end{array}$ & $\begin{array}{l}70 \\
58 \\
22\end{array}$ & $\begin{array}{l}46.7 \\
38.7 \\
14.6\end{array}$ & 0.513 & 0.776 \\
\hline $\begin{array}{cc}\text { Gender } & \\
& \text { Male } \\
& \text { Female }\end{array}$ & $\begin{array}{l}58 \\
42\end{array}$ & $\begin{array}{l}58 \\
42\end{array}$ & $\begin{array}{l}24 \\
26\end{array}$ & $\begin{array}{l}48 \\
52\end{array}$ & $\begin{array}{l}72 \\
78\end{array}$ & $\begin{array}{l}48 \\
52\end{array}$ & 1.345 & 0.247 \\
\hline $\begin{array}{r}\text { Residence } \\
\text { Rural } \\
\text { Urban }\end{array}$ & $\begin{array}{l}59 \\
41\end{array}$ & $\begin{array}{l}59 \\
41\end{array}$ & $\begin{array}{l}28 \\
22\end{array}$ & $\begin{array}{l}56 \\
44\end{array}$ & $\begin{array}{l}87 \\
63\end{array}$ & $\begin{array}{l}58 \\
42\end{array}$ & 0.123 & 0.726 \\
\hline
\end{tabular}

Table.2 Seroprevalence of $T$. canis in epileptic and normal children

\begin{tabular}{|c|c|c|c|c|c|c|c|c|}
\hline & \multicolumn{2}{|c|}{$\begin{array}{l}\text { Epileptic } \\
\text { children } \\
(n=100)\end{array}$} & \multicolumn{2}{|c|}{$\begin{array}{c}\text { Normal } \\
\text { children } \\
(n=50)\end{array}$} & \multicolumn{2}{|c|}{$\begin{array}{c}\text { Total } \\
(\mathbf{n}=150)\end{array}$} & \multirow[t]{2}{*}{$\chi^{2}$} & \multirow[t]{2}{*}{$P$} \\
\hline & n & $\%$ & $\mathrm{n}$ & $\%$ & $\mathbf{n}$ & $\%$ & & \\
\hline $\begin{array}{l}\text { Seropositive with } \\
\text { ELISA only }\end{array}$ & 13 & 13 & 2 & 4 & 15 & 10 & 3.000 & 0.083 \\
\hline $\begin{array}{c}\text { Seropositive with } \\
\text { ELISA and western } \\
\text { blotting }\end{array}$ & 7 & 7 & 0 & 0 & 7 & 4.7 & 3.671 & 0.055 \\
\hline
\end{tabular}


Table.3 Summary of risk factors to toxocariasis in epileptic patients

\begin{tabular}{|c|c|c|c|c|}
\hline \multirow[t]{2}{*}{ Risk factors } & \multicolumn{2}{|c|}{ Seropositive (7) } & \multirow[t]{2}{*}{$\chi^{2}$} & \multirow[t]{2}{*}{$P$} \\
\hline & $\mathbf{n}$ & $\%$ & & \\
\hline \multicolumn{3}{|l|}{$2-<6(45)$} & \multirow[t]{3}{*}{5.572} & \multirow[t]{3}{*}{0.062} \\
\hline $6^{-}<10(40)$ & 3 & 7.5 & & \\
\hline $10-15(15)$ & 4 & 26.7 & & \\
\hline \multicolumn{3}{|l|}{ Male (58) } & \multirow[t]{2}{*}{0.552} & \multirow[t]{2}{*}{0.458} \\
\hline Female (42) & 2 & 4.8 & & \\
\hline $\begin{array}{r}\text { Contact with dogs } \\
\text { Yes }(n=31)\end{array}$ & 5 & 16.1 & \multirow[t]{2}{*}{5.752} & \multirow[t]{2}{*}{$0.016^{*}$} \\
\hline No $(n=69)$ & 2 & 2.9 & & \\
\hline $\begin{array}{r}\text { Contact with soil } \\
\text { Yes }(n=68)\end{array}$ & 7 & 10.3 & \multirow[t]{2}{*}{3.542} & \multirow[t]{2}{*}{0.060} \\
\hline No $(n=32)$ & 0 & 0 & & \\
\hline $\begin{array}{l}\text { Eating raw or } \\
\text { undercooked meat } \\
\qquad \text { Yes }(n=21)\end{array}$ & 2 & 9.5 & \multirow[t]{2}{*}{0.263} & \multirow[t]{2}{*}{0.610} \\
\hline No $(n=79)$ & 5 & 6.3 & & \\
\hline $\begin{array}{l}\text { Residence } \\
\text { Rural (59) }\end{array}$ & 4 & 6.8 & \multirow[t]{2}{*}{0.011} & \multirow[t]{2}{*}{0.918} \\
\hline Urban (41) & 3 & 7.3 & & \\
\hline
\end{tabular}

Table.4 Seroprevalence of $T$. gondii antibodies (IgG and $\operatorname{IgM})$ in epileptic and normal children

\begin{tabular}{|c|c|c|c|c|c|c|c|c|}
\hline & \multicolumn{2}{|c|}{$\begin{array}{l}\text { Epileptic } \\
\text { children } \\
(n=100)\end{array}$} & \multicolumn{2}{|c|}{$\begin{array}{c}\text { Normal } \\
\text { children } \\
(n=50)\end{array}$} & \multicolumn{2}{|c|}{$\begin{array}{c}\text { Total } \\
(n=150)\end{array}$} & \multirow[t]{2}{*}{$\chi^{2}$} & \multirow[t]{2}{*}{$P$} \\
\hline & $\mathbf{n}$ & $\%$ & $\mathbf{n}$ & $\%$ & $\mathbf{n}$ & $\%$ & & \\
\hline T. gondii IgG only & 59 & 59 & 14 & 28 & 73 & 48.7 & 12.820 & 0.001* \\
\hline T. gondii IgM only & 3 & 3 & 3 & 6 & 6 & 4 & $\mathrm{FE}$ & 0.635 \\
\hline T. gondii IgM and IgG & 12 & 12 & 3 & 6 & 15 & 10 & 1.333 & 0.249 \\
\hline
\end{tabular}


Table.5 Summary of risk factors to toxoplasmosis in epileptic patients

\begin{tabular}{|c|c|c|c|c|}
\hline \multirow[t]{2}{*}{ Risk factors } & \multicolumn{2}{|c|}{ Seropositive (74) } & \multirow[t]{2}{*}{$\chi^{2}$} & \multirow[t]{2}{*}{$P$} \\
\hline & $\mathbf{n}$ & $\%$ & & \\
\hline \multicolumn{3}{|l|}{ Age } & \multirow[t]{4}{*}{2.763} & \multirow[t]{4}{*}{0.251} \\
\hline $2-<6(45)$ & 30 & 66.7 & & \\
\hline $6-<10(40)$ & 33 & 82.5 & & \\
\hline $10-15(15)$ & 11 & 73.3 & & \\
\hline \multicolumn{3}{|l|}{ Gender } & \multirow[t]{3}{*}{0.923} & \multirow[t]{3}{*}{0.337} \\
\hline Male (58) & 45 & 77.6 & & \\
\hline Female (42) & 29 & 69 & & \\
\hline $\begin{array}{c}\text { Eating raw or undercooked } \\
\text { meat }(n=21)\end{array}$ & 18 & 85.7 & \multirow[t]{2}{*}{1.902} & \multirow[t]{2}{*}{0.169} \\
\hline No $(n=79)$ & 56 & 70.9 & & \\
\hline Contact with cats $(n=58)$ & 49 & 84.5 & \multirow[t]{2}{*}{7.893} & \multirow[t]{2}{*}{$0.005^{*}$} \\
\hline No $(n=42)$ & 25 & 59.5 & & \\
\hline Unfiltered water $(n=63)$ & 58 & 92 & \multirow[t]{2}{*}{28.881} & \multirow[t]{2}{*}{$0.001 *$} \\
\hline No $(n=37)$ & 16 & 43.2 & & \\
\hline Contact with soil $(n=68)$ & 62 & 91.1 & \multirow[t]{2}{*}{32.587} & \multirow[t]{2}{*}{$0.001 *$} \\
\hline No $(n=32)$ & 12 & 37.5 & & \\
\hline Residence & \multirow[t]{2}{*}{56} & \multirow[t]{2}{*}{94.9} & \multirow[t]{3}{*}{32.391} & \multirow[t]{3}{*}{$0.001 *$} \\
\hline Rural (59) & & & & \\
\hline Urban (41) & 18 & 43.9 & & \\
\hline
\end{tabular}

*Significant $(P<0.05)$

Table.6 The distribution of T. gondii and T.canis antibodies in patients with different types of seizures

\begin{tabular}{|c|c|c|c|c|c|c|c|c|}
\hline \multirow[t]{2}{*}{$\begin{array}{l}\text { Types of } \\
\text { seizures }\end{array}$} & \multicolumn{2}{|c|}{$\begin{array}{c}\text { T. gondii } \\
(\mathrm{n}=74)\end{array}$} & \multirow[t]{2}{*}{$\chi^{2}$} & \multirow[t]{2}{*}{$\boldsymbol{P}$} & \multicolumn{2}{|c|}{$\begin{array}{c}\text { T. canis } \\
(\mathrm{n}=7)\end{array}$} & \multirow[t]{2}{*}{$\chi^{2}$} & \multirow[t]{2}{*}{$P$} \\
\hline & $\mathbf{n}$ & $\%$ & & & $\mathbf{n}$ & $\%$ & & \\
\hline Generalized & 49 & 66.2 & \multirow[t]{3}{*}{55.502} & \multirow[t]{3}{*}{$0.001 *$} & 5 & 71.4 & \multirow[t]{3}{*}{6.862} & \multirow[t]{3}{*}{$0.037 *$} \\
\hline Focal & 16 & 21.6 & & & 1 & 14.3 & & \\
\hline Absence & 9 & 12.2 & & & 1 & 14.3 & & \\
\hline
\end{tabular}

*Significant $(P<0.05)$ 
Figure.1 T. canis western blotting strips Strip one: positive control; Strips (2-5): positive Strip; (6): negative

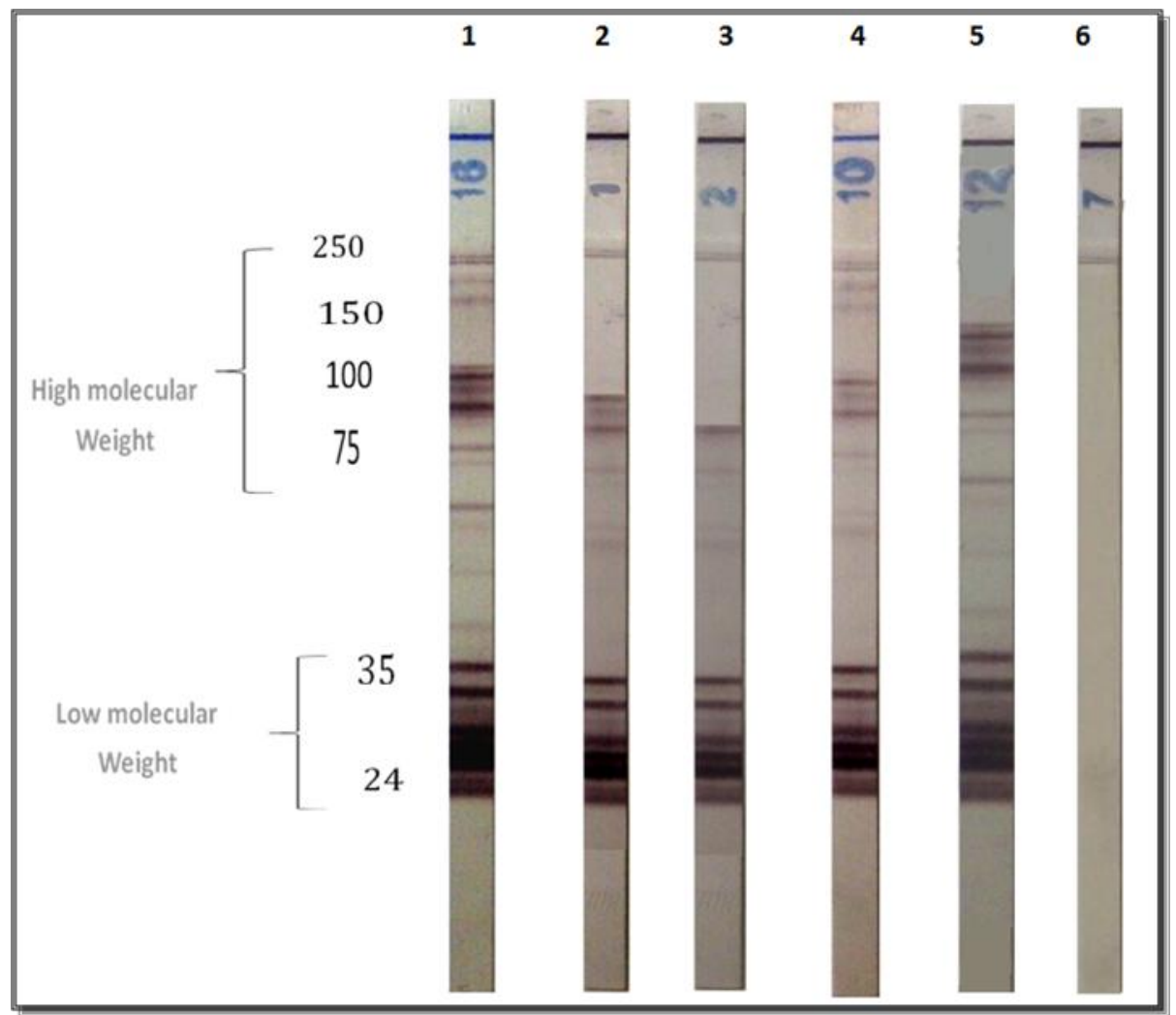

Epilepsy is one of the most common neurological diseases affecting almost $1 \%$ of people worldwide (Thurman et al., 2011). Epidemiological studies have suggested presence of an association between helminthic infections and epilepsy especially in the developing countries (Wanger and Newton, 2009). Regarding toxocariasis, the migrating $T$. canis larvae can reach the human brain causing epileptic foci (Despommier, 2003). Also, T. gondii can form dormant brain cysts which have the potential to cause epilepsy (Stommel et al., 2001). However, such studies are lacking in our geographical location.

In the current study, we found that the frequency of Toxocara infection in epileptic patients was $13 \%$ versus $4 \%$ of the healthy group by ELISA. This finding has a scientific significance despite being statistically insignificant $(P>0.05)$. By western blotting,
anti-Toxocara IgG antibodies were detected in $7(53.8 \%)$ of ELISA positive children in epileptic children group, whereas the serum samples of all ELISA-positive normal children were negative $(P>0.05)$. In accordance with these findings, Zibaei et al., (2013) found that the frequency of Toxocara infection in epileptic patients was $11.8 \%$, scientifically higher than the healthy group $(3.5 \%)$.

Also, Eraky et al., (2016) found no statistically significant difference between epileptic cases and healthy controls $(P>0.6)$ as anti-Toxocara IgG antibodies were detected in 4 epileptic children (3 cases $(7.5 \%)$ in cryptogenic and only 1 case $(3.3 \%)$ in noncryptogenic groups), and 2 seropositive cases $(10 \%)$ only were found in the control subjects. The latter study has the limitation of the small sample size as there were 70 
epileptic children and 20 healthy ones only involved in the study.

Many epidemiological studies have been carried out in different locations to investigate the presence of possible association between epilepsy and $T$. canis seropositivity. A significant association has been reported in many studies. In Burundi, Nicoletti et al., (2007) reported that anti- $T$. canis antibodies were found in 114 epileptic patients (59.7\%) and in 97 controls $(50.8 \%)$. In a study done in Italy, the authors reported that anti-T. canis antibodies were found in 38 epileptic patients (16.4\%) and in 13 controls $(6.6 \%)$ giving a crude OR of 2.85 (Nicoletti et al., 2008). In Iran, Allahdin et al., (2015) found that 28 $(19.85 \%)$ epileptic patients and $2(1.38 \%)$ of healthy people had anti-Toxocara antibodies by ELISA $(P<002)$. Zibaei et al., (2013) concluded that toxocariasis is a risk factor for epilepsy in Iran.

The current study showed the positive western blotting strips, which indicate the presence of specific anti-Toxocara IgG in the samples, with at least two or more bands of low molecular weight between 24 and 35 $\mathrm{kDa}$. These results are similar to those reported in two studies in Iran as the authors have tested anti-Toxocara positive samples with western-blotting method and confirmed the presence of low molecular weight bands in the zone of $24-35 \mathrm{kDa}$ as positive test (Zibaei et al., 2013; Allahdin et al., 2015).

Some pathogenic mechanisms have been proposed to explain the mechanisms of epileptogenesis in toxocariasis. Toxocara larvae could stimulate formation of a granulama around them. An acute granulomatous reaction can cause acute symptomatic seizures, and then may leave after resolution fibrous scars and chronic granulomatous lesions which may lead to epilepsy (Wagner and Newton, 2009). In addition, the increases of the blood brain barrier permeability and the proinflammatory cytokines production due to the presence of Toxocara spp. larvae in the brain may be responsible for neuronal damage (Fan et al., 2015). Similar physiopathological mechanisms have been suggested to be responsible for the epileptogenesis due to neurocysticercosis (Nash et al., 2015). Also, presence of autoantibodies against neuronal elements may play a role in some types of epilepsies (Ganor et al., 2005). The autoimmune nature of epilepsy may be explained by the presence of antibodies to a major excitatory neuro-transmitter in the CNS (Levite and Ganor, 2008) and it was found that toxocariasis stimulates autoantibodies production (Obwaller et al., 2004).

Othman et al., (2010) reported that experimental $T$. canis infection induced several alterations in the brains of infected animals including increased expression of pro-inflammatory cytokines and nitric oxide, neurotransmitter profile disturbances, and astrogliosis. The authors concluded that neurotransmitters level changes especially decreased GABA may explain increased incidence of seizures in children infected with Toxocara.

In helminthic infection, moderate to severe eosinophilia occurs as a part of pathophysiologic response to this infection (Klion and Nutman, 2004). It has been recognized that Toxocara infection is one of the causes of eosinophilia in the peripheral blood and eosinophilic infiltration in internal organs (Kwon et al., 2006). A significant association between eosinophilia and infection by $T$. canis was observed in our study as reported by others (Kwon et al., 2006; Karadam et al., 2008).

As regards association of $T$. canis with the age, gender, residence, contact with soil, and 
eating raw or undercooked meat in this study, there was no statistically significant difference between both groups regarding these factors. In partial accordance with these findings, Zibaei et al., (2013) did not observe any significant difference between either of the seropositive and seronegative patients regarding age and residence in their investigations on adult epileptic patients. In the contrary, El-Tantawy et al., (2013) found that the rate of Toxocara infection in epileptic patients was high in the age group 5-10 years, in male patients, seroprevalence of Toxocara has been reported in rural areas higher than urban areas in other studies of epilepsy.

Concerning the gender, our result is in accordance with Khademvatan et al., (2014) who found that Anti-Toxocara antibodies were detected in $17.14 \%$ of females and $12.3 \%$ of males with schizophrenia disorder and there was no significant difference between gender and positive serology. As regards to the association between toxocariasis and contact with soil, this finding is in accordance with Akyol et al., (2007) who found that there was no significant relationship between pica and Toxocara seropositivity rates in cryptogenic epileptic patients. On the contrary, in Ahvaz in southwestern Iran, a study showed high rates of soil infection in many parts of this city $(46.5 \%)$ and this may be as a risk factor for toxocariasis (Khademvatan et al., 2014). As regard to eating raw or undercooked meat, ElSayed and Ismail (2012) found that seropositivity for $T$. canis was detected in $30.5 \%$ of schizophrenic patients with history of raw food intake and $9.7 \%$ of schizophrenic patients with no history of raw food intake and the difference was statistically significant. Our results may be due to diet changes with age, eating the raw or undercooked meat in the adulthood may increase the risk of exposure to the parasite.
In respect to association of toxocariasis with contact with dogs, the current study showed a high percentage of children with a history of contact with dogs among seropositive group (71.4\%), while a lesser percentage was observed in seronegative group $(27.9 \%)$ and there was a significant difference between the two groups $(P<0.05)$. Also, children who were exposed to dogs were at 6 times higher risk of developing toxocariasis (OR, 6.442; 95\% CI, 1.175-35.307). This is in accordance with Fernando et al., (2007) who reported that children who were in contact to puppies less than 3 months at home were at 17 times higher risk of developing toxocariasis (OR, $17.51 ; 95 \%$ CI, 5.67-56.57). On the contrary, El-Tantawy et al., (2013) found that there was no significant relationship between animal contact and Toxocara seropostivity rates in children with cryptogenic epilepsy.

The current study showed that the most common type of seizures among epileptic children who were seropositive with toxocariasis was the generalized one $(71.4 \%)$ and there was statistically significant difference between the different types of seizures. On the contrary, Nicoletti et al., (2008) concluded that there was significant association between toxocariasis and epilepsy and a stronger association was found with the partial epilepsy. Akyol et al., (2007) found that there was no significant difference between the focal and generalized epilepsy groups regarding seropositivity rate for $T$. canis.

In the current study, patients and control sera were investigated for toxoplasmosis. There was association between Toxoplasma seropositivity and idiopathic epilepsy as there was statistically significant difference in $T$. gondii IgG antibodies between epileptic and normal children $(P<0.05)$. Our results are consistent with many studies in which the authors reported that the level of $T$. gondii 
IgG antibodies showed a statistically significant high value in children with epilepsy (El-Tantawy et al., 2013; Ngoungou et al., 2015). Stommel et al., (2001) suggested that chronic toxoplasmosis with brain cysts may cause cryptogenic epilepsy. In contrast, other studies found that there was no association between epilepsy and toxoplasmosis (Allahdin et al., 2015; Babaie et al., 2017a).

The current study showed that there was no statistical difference between seroprevalence of $\operatorname{IgM}$ in epileptic and healthy children $(P>0.05)$. This finding is in accordance with the study of Yazar et al., (2003) which IgM antibodies were negative in all of the studied epileptic groups. Using the avidity test for patients who have both $T$. gondii $\operatorname{IgG}$ and $\operatorname{IgM}$ antibodies, IgG antibodies of high avidity were detected in $100 \%$ of these sera confirming past infection. This pointed to the possible role of latent toxoplasmosis rather than the recently-acquired infection in seizure disorders.

Many mechanisms could explain the association between toxoplasmosis and epilepsy. Recent evidence indicates that the dormancy of $T$. gondii in the brain is not true as the parasite has a dynamic status within the cysts (Watts et al., 2015) which can alter the function of the neurons by modulation of neurotransmitters such as GABA (Brooks et al., 2015), noradrenaline (Gatkowska et al., 2013), serotonin (Gatkowska et al., 2013), dopamine (Babaie et al., 2017b), glutamate (Kannan et al., 2016) and nitric oxide (Tonin et al., 2014; Dincel and Atmaca 2015). Moreover, T. gondii can increase proinflammatory cytokines level in the serum (Bottari et al., 2015). Therefore, modulation of neurotransmitters profile and increased cytokine levels might be the causes of increased seizure susceptibility by $T$. gondii. Alternatively, the parasite itself is involved in epileptogenesis through rupture of the cysts leading to neuronal injury, or indirectly by immune system activation leading to inflammation and tissue necrosis (Babaie et al., 2017a).

The current study showed that there was no significant difference between different groups regarding age, gender, and consumption of undercooked meat. This result regarding the age was in accordance with Alvarado-Esquivel et al., (2006) who did not detect any association between prevalence of toxoplasmosis and the age of psychiatric patients. On the contrary, Babaie et al., (2017a), in their investigations on adult epileptic patients, found that the $\mathrm{IgG}$ titer of T.gondii significantly increased $(P<0.001)$ with age and the authors found that consumption of undercooked meat was highly correlated with Toxoplasma infection $(P<$ $0.001)$. concerning the gender, our resulte were in accordance with Babaie et al., (2017a) found that there was no correlation between the gender and seropositive rate of $T$. gondii infection in epileptic patients $(P=$ $0.61)$.On the contrary, other studies showed that the seropostivity of toxoplasmosis in epileptic patients were more in males than females (El-Tantawy et al., 2013; Eraky et al., 2016).

The study showed that there was significant association between the residence and prevalence of Toxoplasma. This finding may be attributed to exposure to soil and cat feaces. This is in accordance with many studies that showed that the risk for developing toxoplasmosis in epileptic patients is higher in rural than in urban areas (ElTantawy et al., 2013; Eraky et al., 2016). On the other hand, there are studies which did not find any association between residence and Toxoplasma prevalence in epileptic patients (Akyol et al., 2007; Zibaei et al., 2011). 
The current study showed a statistically significant difference between both groups. Our observation is consistent with that of Eraky et al., (2016) who found that there was significant correlation between Toxoplasma infection and positive history of contact with cats among epileptic patients, as 5 out of the 8 anti-Toxoplasma seropositive cases (62.6\%) gave positive history for contact with animals. Also, in a study done by Meng et al., (2015), the authors found that raising cats at home seemed to be a main risk factor. On the contrary, El-Tantawy et al., (2013) found that there was no significant relationship between animal contact and Toxoplasma seropostivity rate in children with cryptogenic epilepsy.

In respect to the association of toxoplasmosis with source of water, the current study showed that epileptic children drinking unfiltered water were at 15 times higher risk of developing toxoplasmosis (OR, 15.225; 95\% CI, 4.961-46 .728). This may be explained as the general network supply of water in our cities is generally not well treated. To our knowledge, there was no available study investigating this risk factor in epileptic patients. However; in a study in Cameroon, the authors reported a higher prevalence $(75.58 \%)$ in people having the general network supply as a source of drinking water (Njunda et al., 2011). Using concentration of water via Fluoropore ${ }^{\circledR}$ membranes followed by bioassay in Brazil, $T$. gondii were isolated and implicated in a large waterborne outbreak (de Moura et al., 2006). Okwuzu et al., (2015) reported that source of water and drinking unpasteurized cow milk were risk factors of toxoplasmosis.

The current study showed that contact with soil is an important risk factor for toxoplasmosis as there was significant difference between seropositive and seronegative groups in epileptic children. Likewise, Allahdin et al., (2015) found that contact with soil and cat may increase the chance of infection in epileptic patients. Moreover, Gyang et al., (2015) who investigated the seroprevalence and risk factors of toxoplasmosis among primary schoolchildren, reported that the high seroprevalence of $T$. gondii in children was attributed to their frequent contact with contaminated soil. On the contrary, Babaie et al., (2017a) found that there was no significant difference between seropositive and seronegative groups in epileptic patients regarding contact with soil $(P=0.062)$. The latter finding may be due to the age of participants as they were adult persons $(<30-$ $>50$ years old).

The current study showed that out of 74 epileptic children who were seropositive for toxoplasmosis, $66.2 \%$ had generalized convulsions, $21.6 \%$ had focal convulsions, $12.2 \%$ had absence epilepsy and there was statistically significant difference between the different types of convulsions. These findings are in accordance with Eraky et al., (2016) who found that $12.5 \%$ of cases had focal convulsions and $87.5 \%$ of cases had generalized convulsions. On the contrary, Akyol et al., (2007) found that there was no significant difference between types of seizures (focal and generalized) regarding $T$. gondii seropositivity rate. Cerebral toxoplasmosis has been reported to cause seizures by producing diffuse encephalitis or localized lesions (Neto and De Bittencourt, 1996).

In conclusion, the current study highlighted the association between toxoplasmosis and idiopathic epilepsy.

As regards toxocariasis, there was no statistically significant difference in Toxocara seropositivity between patient and control group; however toxocariasis should be considered a latent risk factor especially in 
rural localities. Moreover, it identified the epidemiological variables and risk factors associated with toxoplasmosis and toxocariasis which are key steps for raising the public awareness and for implementation of different levels of prevention and control strategies.

\section{Acknowledgments}

I would like to express my greatthanks to Dr. Khaled Temsah, Lecturer of Parasitology, Dr. Muhammad Tarek Abdel ghafar, Lecturer of Clinical Pathology, and Dr. Marwa ElHadad, Assistant Lecturer of Clinical Pathology for their help and cooperation.

\section{References}

Akyol, A., Bicerol, B., Ertug, S., Ertabaklar, H. and Kiylioglu, N., 2007. Epilepsy and seropositivity rates of Toxocara canis and Toxoplasma gondii. Seizure 16 (3): 233-237.

Allahdin, S., Khademvatan, S., Rafiei, A., Momen, A. and Rafiei, R., 2015. Frequency of Toxoplasma and Toxocara sp. antibodies in epileptic patients, in south western Iran. Iran. J. Child. Neurol. 9 (4), 32-40.

Alvarado-Esquivel, C., Alanis-Quinones, O.P., Arreola-Valenzuela, M.A., Rodriguez-Briones, A., Piedra-Nevarez, L.J., Duran-Morales, E., et al., 2006. Seroepidemiology of Toxoplasma gondii infection in psychiatric inpatients in a northern Mexican city. BMC Infect. Dis. 6, 178-184.

Babaie, J., Sayyah, M., Fard-Esfahani, P., Golkar, M. and Gharagozli, K., 2017b. Contribution of dopamine neurotransmission in proconvulsant effect of Toxoplasma gondii infection in male mice. J. Neurosci. Res. 95 (10), 1894-1905.

Babaie, J., Sayyah, M., Gharagozli, K.,
Mostafavi, E. and Golkar, M., 2017a. Seroepidemiological study of Toxoplasma gondii infection in population of Iranian epileptic patients. EXCLI Journal 16, 256-264.

Baca, C.B., Vickrey, B.G., Caplan, R., Vassar, S.D. and Berg, A.T., 2011. Psychiatric and medical comorbidity and quality of life outcomes in childhood-onset epilepsy. Pediatrics 128, 1532-1543.

Bell, G.S., Neligan, A. and Sander , J.W., 2014. An unknown quantity the worldwide prevalence of epilepsy. Epilepsia 55, 958-962.

Bottari, N.B., Baldissera, M.D., Tonin, A.A., Rech, V.C., Nishihira, V.S., Thome, G.R., et al., 2015. Effects of sulfamethoxazole- trimethoprim associated to resveratrol on its free form and complexed with 2-hydroxypropylbetacyclodextrin on cytokines levels of mice infected by Toxoplasma gondii. Microb. Pathog. 87, 40-44.

Brooks, J.M., Carrillo, G.L., Su, J., Lindsay, D.S., Fox, M.A. and Blader, I.J., 2015. Toxoplasma gondii infections alter GABAergic synapses and signaling in the central nervous system. MBio 6 (6), e01428-15.

Camfield, P. and Camfield, C., 2015. Incidence, prevalence and aetiology of seizures and epilepsy in children. Epileptic Disord. 17, 117-123.

Congdon, P., and Lloyd, P., 2011. Toxocara infection in the United States: the relevance of poverty, geography and demography as risk factors, and implications for estimating county prevalence. Int. J. Public Health 56, 1524.

Dacie, J.V., and Lewis, S.M., 1992. Basic Haematological Techniques. In: Practical Haematology. Churchil Livingstone, London, pp. 54-55.

de Moura, L., Bahia-Oliveira, L.M.G., Wada, 
M.Y., Jones, J.L., Tuboi, S.H., Carmo, E.H., et al., 2006. Waterborne toxoplasmosis, Brazil, from field to gene. Emerg. Infect. Dis. 12, 326-329.

Despommier, D., 2003. Toxocariasis: clinical aspects, epidemiology, medical ecology, and molecular aspects. Clin. Microbiol. Rev. 16 (2), 265-272.

Dincel, G.C. and Atmaca, H.T., 2015. Nitric oxide production increases during Toxoplasma gondii encephalitis in mice. Exp. Parasitol. 156, 104-112.

Dubey, J.P. and Jones, J.L., 2008. Toxoplasma gondii infection in humans and animals in the United States . Int. J. Parasitol. 38, $125-1278$.

El-Sayed, N.M. and Ismail, K.A., 2012. Relationship between Toxocara canis infection and schizophrenia. Rawal Med. J. 37 (2), 155-161.

El-Tantawy, N.L., El-Nahas, H.A., Salem, D.A., Salem, N.A. and Hasaneen, B.M., 2013. Seroprevalence of Toxoplasma gondii and Toxocara spp. in children with cryptogenic epilepsy. Am. J. Infect. Dis. Microbiol. 1, 92-95.

Eraky, M.A., Abdel-Hady, S., and Abdallah, K.F., 2016. Seropositivity of Toxoplasma gondii and Toxocara spp. in Children with Cryptogenic Epilepsy, Benha, Egypt. Korean J. Parasitol. 54(3), 335-338.

Fan, C.K., Holland, C.V., Loxton, K. and Barghouth, U., 2015. Cerebral Toxocariasis: silent progression to neurodegenerative disorders? Clin. Microbiol. Rev. 28 (3), 663-686.

Fan, C.K., Liao, C.W., and Cheng, Y.C., 2013. Factors affecting disease manifestation of toxocarosis in humans: genetics and environment. Vet. Parasitol. 193 (4), 342-352.

Fernando, S.D., Wickramasinghe, V.P., Kapilananda, G.M.G., Devasurendra, R.L., Amarasooriya, J.D.M.S., and Dayaratne, $\quad$ H.G.A.K., 2007.
Epidemiological aspects and risk factors of toxocariasis in a pediatric population in Srilanka. Southest Asian J. Trop. Med. public health 38 (6): $157-62$.

Figueiredo, S.D., Taddei, J.A., Menezes, J.J., Novo, N.F., Silva, E.O., Cristóvão, H.L., et al., 2005. Clinicalepidemiological study of toxocariasis in a pediatric population. J. Pediatr. 81 (2): $126-132$.

Ganor, Y., Goldberg-Stern, H., Lerman-Sagie, T., Teichberg, V.I. and Levite, M., 2005. Autoimmune epilepsy: distinct subpopulations of epilepsy patients harbor serum autoantibodies to either glutamate/AMPA receptor GluR3, glutamate/NMDA receptor subunit NR2A or double-stranded DNA. Epilepsy Res. 65 (1): 11-22.

Gatkowska, J., Wieczorek, M., Dziadek, B., Dzitko, K. and Dlugonska, H., 2013. Sex-dependent neurotransmitter level changes in brains of Toxoplasma gondii infected mice. Exp. Parasitol. 133, 1-7.

Gyang, P.V., Akinwale, P.O., Lee, Y., Chuang, T., Orok, A., Ajibaye, O., et al., 2015. Toxoplasma gondii infection: seroprevalence and associated risk factors among primary schoolchildren in Lagos City, Southern Nigeria. Rev. Soc. Bras. Med. Trop. 48, 56-63.

Karadam, S.Y., Ertug, S., Ertabaklar, H., Okyay, P., 2008. The comparison of IgG antibodies specific to Toxocara spp. among eosinophilic and noneosinophilic groups. New Microbiol. 31, 113-116.

Khademvatan, S., Khajeddin, N., Izad, S., Yousefi E., 2014. Investigation of AntiToxocara and Anti-Toxoplasma Antibodies in Patients with Schizophrenia Disorder. Schizophr. Res. Treatment. http://dx.doi.org/ 10.1155/2014/230349.

Klion, A.D., and Nutman, T.B., 2004. The role of eosinophils in host defense 
against helminth parasites. J. Allergy

Clin. Immunol. 113, $30-37$.

Kwon, N.H., Oh, M.J., Lee, S.P. and Choi, D.C., 2006. The prevalence and diagnostic value of toxocariasis in unknown eosinophilia. Ann. Hematol. $85,233-238$.

Levite, M. and Ganor, Y., 2008. Autoantibodies to glutamate receptors can damage the brain in epilepsy, systemic lupus erythematosus and encephalitis. Expert. Rev. Neurother. 8 (7): 1141-1160.

Macpherson, C.N., 2013. The epidemiology and public health importance of toxocariasis: a zoonosis of global importance. Int. J. Parasitol. 43, 9991008.

Meng, Q-F., You, H.L., Zhou, N., Dong, W., Wanga, W.L., Wang W.L., et al., 2015. Seroprevalence of Toxoplasma gondii antibodies and associated risk factors among children in Shandong and Jilin provinces, China. Int. J. Infect. Dis. 30, 33-35.

Miller, C.M., Boulter, N.R., Ikin, R.J., and Smith, N.C. 2009. The immunobiology of the innate response to Toxoplasma gondii. Int. J. Parasitol. 39, 23-39.

Montoya, J.G., and Liesenfeld, O., 2004. Toxoplasmosis. Lancet. 363, 19651976.

Nash, T.E., Mahanty, S., Loeb, J.A., Theodore, W.H., Friedman, A., Sander, J.W., et al., 2015. Neurocysticercosis: A natural human model of

epileptogenesis. Epilepsia. 56 $177-183$

Neto, M.C. and De Bittencourt, P.R.M., 1996. Infections and post-infective causes. In: Wallace, S. (Ed.), Epilepsy in Children. Madras, Chapman \& Hall, pp. 79-86.

Ngoungou, E.B., Bhalla, D., Nzoghe, A., Dardé, M. and Preux, P., 2015. Toxoplasmosis and epilepsy systematic review and meta- analysis.
PLOS Negl. Trop. Dis. 9 (2): e0003525. Nicoletti, A., Bartoloni, A., Sofia, V., Mantella, A., Nsengiyumva, G., Frescaline, G. and Preux, P.M., 2007. Epilepsy and toxocariasis: a casecontrol study in Burundi. Epilepsia 48, 894-899.

Nicoletti, A., Sofia, V., Mantella, A., Vitale, G., Contrafatto, D., Sorbello, V., et al., 2008. Epilepsy and toxocariasis: a casecontrol study in Italy. Epilepsia 49, 594-599.

Nicoletti, A., Sofia, V., Mantella, A., Vitale, G., Contrafatto, D., Sorbello, V., et al., 2008. Epilepsy and toxocariasis: a casecontrol study in Italy. Epilepsia 49, 594-599.

Njunda, A.L., Assob, J.C.N., Nsagha, D.S., Kamga, H.L., Nde, P.F., Yugah, V.C., 2011. Seroprevalence of Toxoplasma gondii infection among pregnant women in Cameroon. Journal of Puplic Health in Africa (JPHiA). 2 (2), e24.

Obwaller, A., Duchene, M., Walochnik, J., Wiedermann, G., Auer, H. and Aspock, H., 2004. Association of autoantibodies against small nuclear ribonucleoproteins (snRNPs) with symptomatic Toxocara canis infestation. Parasite Immunol. 26, 327-333.

Okwuzu, J.O., Otubanjo, A.O., Ezechi, O.C., Idowu, E.T., Odunukwe, N.N., Okoye, R.N., et al., 2015. Toxoplasma gondii infection among HAART-naive HIVpositive patients and HIV-negatives in Lagos State, Nigeria. Int. J. Microbiol. Immunol. Res. 3, 1-8.

Oryan, A., Sadjjadi, S.M. and Azizi, S., 2010. Longevity of Toxocara cati larvae and pathology in tissues of experimentally infected chickens. Korean J. Parasitol. 48, 79-80.

Othman, A.A., Abdel-Aleem, G.A., Saied, E.M., Mayah, W.W. and Elatrash, A.M., 2010. Biochemical and immunopathological changes in 
experimental neurotoxocariasis. Mol. Biochem. Parasitol. 172, 1-8

Sander, J.W. and Perucca, E., 2003. Epilepsy and comorbidity : infections and antimicrobials usage in relation to epilepsy management . Acta. Neurol. Scand., 108, 16-22.

Singh, V., Gomez, V.V., Swamy, S.G. and Vikas, B., 2009. Approach to a case of eosinophilia. The International Journal of Agile Systems and Management (IJASM) 53 (2): 58-64.

Stommel, E.W., Seguin, R., Thadani, V.M., Schwartzman, J.D., Gilbert, K., Ryan K.A., et al., 2001. Cryptogenic epilepsy: an infectious aetiology? Epilepsia 42 (3): 436-438.

Tenter, A.M., Heckeroth, A.R. and Weiss, L.M., 2000. Toxoplasma gondii: from animals to humans. Int. J. Parasitol. 30, 1217-1258.

Thurman, D.J., Beghi, E., Begley, C.E., Berg, A.T., Buchhalter, J.R., Ding, D., et al., 2011. ILAE Commission on Epidemiology. ILAE Epidemiology Commission Report. Standards for epidemiologic studies and surveillance of epilepsy. Epilepsia. 52, 2-26.

Tonin, A.A., Da Silva, A.S., Thome, G.R., Sangoi, M.B., Oliveira, L.S., Flores, M.M., et al., 2014. Influence of toxoplasmosis on acetylcholinesterase activity, nitric oxide levels and cellular lesion on the brain of mice. Pathol. Res. Pract. 210, 526-532.

Wagner R.G. and Newton C.R., 2009. Do helminths cause epilepsy? Parasite Immunol. 31, 697-705.

Watts, E., Zhao, Y., Dhara, A., Eller, B., Patwardhan, A., Sinai, A.P., 2015. Novel approaches reveal that Toxoplasma gondii bradyzoites within tissue cysts are dynamic and replicating entities in vivo. MBio. 6 (5): e0115-15.

Yazar, S., Arman, F., Yalcin, S., Demirta, F., Yaman, O. and Sahin, I., 2003. Investigation of probable relationship between Toxoplasma gondii and cryptogenic epilepsy. Seizure. 12, 107109.

Zibaei, M., Firoozeh, F., Bahram, P. and Sadjjadi, S.M., 2013. Investigation of Anti-Toxocara antibodies in epileptic patients and comparison of two methods: ELISA and Western blotting. epilepsy Res. Treat. e156815.

Zibaei, M., Zamani, Z., Esfahani, A.C., Anbari, K. and Nezar, M.R., 2011. Toxoplasma infection and epilepsy: a case-control study in Iran. Neurol. Asia 16, 299-302.

\section{How to cite this article:}

Amina M. Salama, Ahmed A. Daoud, Azza K. Elshehawy, Ahmad A. Othman, Mohamed M. Eid. 2019. Toxocariasis and Toxoplasmosis in Children with Idiopathic Epilepsy in MidRegion of the Nile Delta, Egypt: Prevalence and Risk Factors. Int.J.Curr.Microbiol.App.Sci. 8(02): 760-775. doi: https://doi.org/10.20546/ijcmas.2019.802.088 